\title{
Acute Oral Toxicity and Brine Shrimp Lethality of Methanol Extract of Mentha Spicata L (Lamiaceae)
}

\author{
Jegathambigai R Naidu ${ }^{1,2}$, Rusli Ismail ${ }^{1}$ and Sreenivasan Sasidharan ${ }^{1 *}$ \\ ${ }_{1}^{1}$ Institute for Research in Molecular Medicine (INFORMM), Universiti Sains Malaysia, Pulau Pinang 11800, ${ }^{2}$ Department of \\ Biochemistry, Faculty of Medicine, AIMST University, Semeling-Bedong 08100, Kedah, Malaysia
}

${ }^{*}$ For correspondence: Email: srisasidharan@yahoo.com; Tel: +604-653-4820; Fax: +604-653-4803

\begin{abstract}
Purpose: To determine, in Sprague Dawley rats, the toxicity profile of the methanol extract of Mentha spicata, a plant used in folklore medicine for the treatment of various forms of pain.

Methods: The plant extract, at concentrations ranging from $100-0.07 \mathrm{mg} / \mathrm{ml}$, was used to determine the median lethal concentration $\left(L C_{50}\right)$ based on brine shrimp lethality assay. Artificial sea water served as control. Acute oral toxicity testing was carried out, according to the Organisation for Economic Co-operation and Development (OECD) guidelines, based on serum biochemical analysis and histological investigations of liver, kidney, heart, spleen and lungs.

Results: The $L C_{50}$ value of Mentha spicata was $1701 \mu \mathrm{g} / \mathrm{ml}$ in brine shrimp lethality assay, indicating that the plant extract is non-toxic. For acute toxicity testing, administration of a single dose of $5000 \mathrm{mg} / \mathrm{kg}$ extract to the rats did not produce toxicity, in terms of changes in behaviour or mortality. Moreover, the weight of major organs of the animals did not significantly $(p>0.05)$ differ from those of the control group. No toxicologically significant $(p>0.05)$ hematological and biochemical changes were noticed between animals treated with the plant extract and control animals. Treatment with plant extract did not cause any morphological changes in the heart, liver, kidney and lung tissues of the rats. Histopathological examination also did not reveal any toxicity evidence in the extract-treated animals.
\end{abstract}

Conclusion: The results obtained suggest that the plant extract can be classified as non-toxic.

Keywords: Mentha spicata, Acute toxicity, Brine shrimp, Histopathology, Haematological.

Tropical Journal of Pharmaceutical Research is indexed by Science Citation Index (SciSearch), Scopus, International Pharmaceutical Abstract, Chemical Abstracts, Embase, Index Copernicus, EBSCO, African Index Medicus, JournalSeek, Journal Citation Reports/Science Edition, Directory of Open Access Journals (DOAJ), African Journal Online, Bioline International, Open-J-Gate and Pharmacy Abstracts

\section{INTRODUCTION}

Plants have been utilized as medicines for thousands of years in the form of crude drugs such as tinctures, teas, poultices, powders, and other herbal formulations [1,2]. Mentha spicata (Lamiaceae), locally known as "Pudina" is a perennial herb with a characteristic spearmint odor. The fresh and dried plants and their essential oil are used in food, cosmetic, confectionary, chewing gum, toothpaste and pharmaceutical industries $[3,4]$. It is well documented that the essential oil from Mentha species posses anti-microbial and antioxidant properties. This herb is considered a stimulant, carminative, antispasmodic, stomachic and diuretic and is used in the treatment of gas pain, rheumatism, toothache, muscle pain. Mint possesses antimicrobial and antioxidant properties due to the presence of active constituents like menthone, menthol, rosmaninric acid and carvone [5-7]. The data of the toxicity studies on medicinal plants or preparations derived from them should be obtained in order to increase the confidence in their safety to humans, particularly for use in the development of pharmaceuticals. Therefore, evaluating the 
toxicological effects of Mentha spicata extract intended to be used in animals or humans is a crucial part of its assessment for potential toxic effects.

In the present study, the methanol extract of Mentha spicata, was subjected to brine shrimp lethality bio-assay and oral acute toxicity study at single high dose of $5000 \mathrm{mg} / \mathrm{kg}$ in rats to determine its toxicity range and thus ascertain whether or not its possible toxicity could militate against the claim of its therapeutic potential. Biochemical and histological assessments also done to further verified the toxicity of Mentha spicata.

\section{EXPERIMENTAL}

\section{Plant sample preparation}

Mentha spicata was collected from the small farms around the Bedong and Semeling regions of Sungai Petani, Kedah, Malaysia. A voucher specimen (no. 11295) was submitted to the herbarium unit, Universiti Sains Malaysia. The aerial parts of the plant sample was washed thoroughly under running tap water and dried at room temperature $\left(30^{\circ} \mathrm{C}\right)$ for a week. The dried plant material was ground to fine powder using an electrical blender, transferred to a clean dry glass container and stored until extraction. The powder $(100 \mathrm{~g})$ was soaked in absolute methanol $(80 \% \mathrm{v} / \mathrm{v})$ for 4 days with frequent agitation. The Mentha spicata extract formulation was prepared in $0.5 \%$ Tween 80 as vehicle and this was done not longer than $4 \mathrm{~h}$ prior to dosing. The formulation was placed on a magnetic stirrer during dosing to ensure adequate dispersion. Adjustment was made for specific gravity and purity of the extract to ensured that the extract is pure or correct concentration was used for toxicity study.

\section{Brine shrimp lethality bioassay}

Brine shrimp lethality bioassay is considered a useful tool for preliminary assessment of toxicity. The method is attractive, because it is very simple, inexpensive and sensitive [8]. Brine shrimp eggs, Artemia salina were hatched in artificial sea water prepared by dissolving $38 \mathrm{~g}$ sodium chloride in 1

liter of distilled water under constant aeration and light source $\left(29^{\circ} \mathrm{C}\right)$ for $48 \mathrm{~h}$. After hatching, the larvae (active nauplii) were separated from the shells and unhatched eggs by siphoning with a plastic tube. Ten nauplii were drawn through a glass capillary and placed in a vial containing 4.5 $\mathrm{ml}$ of artificial sea water solution and $0.5 \mathrm{ml}$ of the diluted plant extract $(100-0.07 \mathrm{mg} / \mathrm{ml})$ was added to it and maintained at room temperature for $24 \mathrm{~h}$ under constant aeration and light source. The test was carried out on both control (artificial sea water), plant extract and potassium dichromate at a concentration range of 1.95 $1000 \mu \mathrm{g} / \mathrm{ml}(\mathrm{n}=3)$, and mortality computed as in Eq $1[9,10]$.

Mortality $(\%)=$ Sc - St

where Sc is \% nauplii that survived for control while St is \% nauplii that survived the treatment.

\section{Determination of lethal concentration $\left(\mathbf{L C}_{50}\right)$}

Lethality was calculated from the mean survival of larvae in extract-treated tubes and that of control. Mean percentage mortality was plotted against the logarithm of concentrations. The concentration killing $50 \%$ of the larvae $\left(\mathrm{LC}_{50}\right)$ was calculated from the linear equation by taking the antilogarithm. Potassium dichromate was used as positive control.

\section{Experimental animals}

Sprague-Dawley female rats (nulliparous, 12 - 14 weeks old) were obtained form the Animal House, University Science Malaysia (USM). The experimental procedure was approved by AIMST University, Human and Animal Ethical Committee (AUHAEC 75/FOM/2012). The animals were housed in a well-ventilated animal house with 12h/12-h light/dark cycle, and easy access to water and standard pellet diet. The animals were randomly selected, marked to permit individual identification, and kept in their cages for at least 5 - 7 days prior to dosing to allow for acclimatization to laboratory conditions.

\section{Acute toxicity studies}

Experimental procedure and handling of animals was carried out according to the OECD testing guidelines [39]. One measure of acute toxicity is the lethal dose $50\left(L_{50}\right)$, i.e., the dose of a substance that kills $50 \%$ of the animals tested. The animals $(n=6)$ were treated with a single dose of $5000 \mathrm{mg} / \mathrm{kg}$ of Mentha spicata extract by oral gavage (with the volume of $10 \mathrm{ml} / \mathrm{kg}$ body weight of the rats) after overnight fast. The control group received only the vehicle $(0.5 \%$ Tween 80). Utmost care was taken to avoid the entry of the gavage to the breathing system of the rats during the gavage feeding. After the extract was administered, feed but not water was withheld for $3-4 \mathrm{~h}$ and the animals was monitored for 14 days. Mortality rate and body weight were recorded weekly. At the end of the 
experiment, the rats were anesthetized using diethyl ether and blood was drawn using direct cardiac puncture. At the end of the experiment, the rats were anesthetized using diethyl ether, sacrificed by cervical dislocation, and subjected to gross necropsy and dissection. Major vital whole organs (liver, kidney, heart, spleen and lungs) were removed and stored in formalin pending histopathological studies [11].

\section{Visual observation}

Physical examination of the animals was performed prior to commencement of treatment to ensure that the animals are in a good state of health. The mice were closely observed for any indications of toxicity effect within the first eight hours after the treatment period, and daily further for a period of 14 days. Surviving animals were weighed daily and visual observations for mortality, behavioral pattern changes such as weakness, aggressiveness, food or water refusal, diarrhea, salivation, discharge from eyes and ears, noisy breathing, changes in locomotor activity, clonic convulsion, coma, injury, pain or any signs of illness in each treated group were monitored carefully on daily basis throughout the experiment period. No deaths were reported in this study, suggesting that the $L D_{50}$ is higher than $5000 \mathrm{mg} / \mathrm{kg}$.

\section{Hematological and biochemical assessment}

Blood samples of extract treated and control groups were drawn from the retro-orbital sinus and $0.5 \mathrm{ml}$ of blood was collected into EDTA tubes for hematological parameters, $0.9 \mathrm{ml}$ in citrated tubes for clotting tests, and $0.5 \mathrm{ml}$ in heparin tubes for clinical biochemistry tests. For hematological testing, red blood cell (RBC), white blood cell (WBC) count, differential leukocyte count(DLC) , neutrophils, lymphocytes, eosinophils, basophils, reticulocytes, platelets, hemoglobin level and hematocrit values were determined using the manufacturer's test kit (Gribble's Lab, Penang, Malaysia). For clinical biochemistry tests, alanine aminotransferase (ALT), aspartate aminotransferase (ALT), alkaline phosphatase, total protein, sodium, potassium, chloride, calcium, inorganic phosphate were analyzed using the manufacturer's test kit (Gribble's Lab, Penang, Malaysia).

\section{Histopathological examination}

The descriptions of all the macroscopic abnormalities of the sacrificed and necropsied animals were recorded. Tissues from the liver, lung, heart and kidney were ixed in neutral phosphate buffered $4 \%$ formaldehyde solution for histological examination [12]. Organ weight as well as animal weight after sacrifice was recorded.

\section{Statistical analysis}

Lethality (\%) was calculated from the mean survival larvae for both extract-treated and control groups. $\mathrm{LC}_{50}$ values were obtained from the best-fit line by regression analysis. One-way ANOVA was carried out using IBM's SPSS, version 20, software to determine tcorrelation and differences. Confirmation of statistical difference was by Tukey and LSD tests ( $p<$ 0.05).

\section{RESULTS}

\section{Brine shrimp lethality}

The $\mathrm{LC}_{50}$ value for the percentage of mortality brine shrimp treated with Mentha spicata extracts as indicated by the regression equation $\left(R^{2}=\right.$ 0.8520 ) was found to be $1701 \mu \mathrm{g} / \mathrm{ml}$. The value was significantly $(p<0.05)$ higher when compared to the standard potassium dichromate (LC50 = $164.03 \mu \mathrm{g} / \mathrm{ml}$. In addition there was also a significant correlation $(p<0.05)$ between the concentration of the extracts, used and the percentage of mortality value, it was found to be increased with increase in the concentration for all the plants tested and the standard as proven by Tukey's test.

\section{Acute toxicity}

The acute toxicity study was conducted as per the OECD guidelines 425, where the limit test dose of $5000 \mathrm{mg} / \mathrm{kg}$ was used. No treatmentrelated mortality was observed at $5000 \mathrm{mg} / \mathrm{kg}$. Throughout 14 days of observation, there were no significant $(p>0.05)$ changes recorded in behavior in any of the animals such as apathy, hyperactivity, morbidity, etc. No abnormal changes attributable to treatment were noticed in body weights and treatment-related changes like respiration rate and heart

rate. Therefore, the extract seems to be safe at a dose level of $5000 \mathrm{mg} / \mathrm{kg}$, and the $L_{50}$ is considered be $>5000 \mathrm{mg} / \mathrm{kg}$. There were no clinical signs of toxicity or treatment-related mortality during the observation period among the rats. The animals appeared very healthy and their physical activity appeared normal.

\section{Body and organ weights}

There were no toxicologically significant $(p>$ 0.05 ) changes in body and weight weight of the 
animals treated with the extract when compared to control (Figure 1).
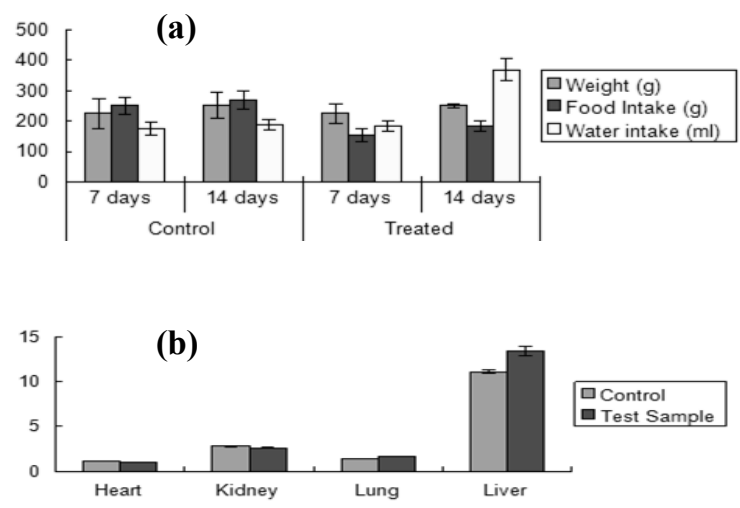

Figure 1: Effect of single dose administration of the plant extract on (a) body weight, food and water intake, and (b) organ weight

\section{Food consumption}

Food consumption levels of animals treated with the plant extract were affected when compared to the control. The differences were significant ( $p$ $<0.05)$ compared to control rats. Food intake was lower in weeks 1 and 2 of the treatment phase of the extract-treated animals (Figure 1a).

\section{Hematological profile}

The results of the hematological tests are summarized in Table 1 . All the tested hematological parameters including hemoglobin, total blood count, total white blood cell, neutrophil, lymphocyte, eosinophil, monocyte, basophil, packed cell volume, and platelet count were within normal limits. No toxicologically significant differences $(p>0.05)$ between animals treated with the plant extract and control were found.

\section{Clinical biochemistry}

The results of the various biochemical tests on the animals treated with the plant extract are summarized in Table 2 . The following changes in clinical biochemistry parameters distinguished treated animals from control animals. Oral administration of single dose the plant (5000 $\mathrm{mg} / \mathrm{kg}$ ) extract did not cause significant changes in total protein, albumin, globulin, albumin/globulin ratio, total bilirubin, alkaline phosphatase, alanine transaminase (ALT), aspartate transaminase (AST), gamma glutamyl transferase (GGT), urea, potassium, sodium, chloride, creatinine and uric acid levels of the plant extract treated animals. The biochemical parameters such as serum total bilirubin, AST, ALT, GGT, serum total proteins, serum total albumin and serum total globulin were within the normal level.

Table 1: Effect of single oral administration of the plant extract $(5000 \mathrm{mg} / \mathrm{kg})$ on hematological parameters (mean \pm SEM, $n=5)$

\begin{tabular}{lll}
\hline $\begin{array}{l}\text { Hematological } \\
\text { parameter }\end{array}$ & Control & $\begin{array}{l}\text { Plant } \\
\text { extract }\end{array}$ \\
\hline $\begin{array}{l}\text { Haemoglobin }(\mathrm{g} / \mathrm{l}) \\
\begin{array}{l}\text { Total red blood cell }(\mathrm{x} \\
\left.10^{12} / \mathrm{L}\right)\end{array}\end{array}$ & $172.00 \pm 4.24$ & $163.80 \pm 8.04$ \\
Total white blood cell $(\mathrm{x}$ & $11.70 \pm 7.70$ & $8.70 \pm 3.50$ \\
$\left.10^{9} / \mathrm{L}\right)$ & & $11.90 \pm 0.73$ \\
Neutrophil $(\%)$ & $36.00 \pm 7.07$ & $29.00 \pm 2.10$ \\
Lymphocyte $(\%)$ & $64.00 \pm 2.70$ & $69.00 \pm 4.00$ \\
Monocyte $(\%)$ & $6.70 \pm 0.40$ & $6.08 \pm 1.80$ \\
Eosinophil $(\%)$ & $0.00 \pm 0.00$ & $2.00 \pm 0.00$ \\
Basophil $(\%)$ & $0.00 \pm 0.00$ & $0.00 \pm 0.00$ \\
Packed cell volume $(\mathrm{L} / \mathrm{L})$ & $0.50 \pm 0.03$ & $0.48 \pm 0.02$ \\
Platelet count $\left(\mathrm{x} 10^{y} / \mathrm{L}\right)$ & $789.0 \pm 21.4$ & $933.0 \pm 172.5$ \\
\hline
\end{tabular}

\section{Histological characteristics}

Histological examination did not reveal any significant morphological changes in the heart, kidney, liver and lung sections of the treated animals when compared to the control. The tissue sections did not show any gross lesions. Heart sections of both control and treated rats showed myocardium with branched muscle fibers (Figure 3(a)). Kidney tissues from control and plant extract-treated group showed the presence of renal corpuscles and glomerulus (Figure 3(b)). The liver sections of the two animal groups indicate well-defined hepatocytes interspaced with hepatic sinusoids (Figure 3(c)). Alveolar sacs and alveoli were present in the lung sections of both animal groups (Figure $3 \mathrm{~d}$ ). Treatment with plant extracts did not cause any morphological changes in the heart, liver, kidney and lung tissues of the rats. Thus, a single oral dose of Mentha spicata extract $(5000 \mathrm{mk} / \mathrm{kg})$ did not produce any significant morphological changes in female SD rats.

\section{DISCUSSION}

Brine shrimp lethality bioassay (BST) is an efficient, rapid and inexpensive assay for testing the bioactivity of plant extracts. It is an excellent choice for elementary toxicity investigations based on the ability to kill laboratory-cultured Artemia naupli [13]. Studies have demonstrated a positive correlation between the brine shrimp lethality and oral lethality test in mice in medicinal plant research [14]. In the present study, the brine shrimp lethality bioassay was performed to assess the preliminary toxicity of Mentha spicata. Even though the brine shrimp test does not provide any adequate information regarding the 
Table 2: Effect of single dose administration of the plant extract $(5000 \mathrm{mg} / \mathrm{kg})$ on biochemical parameters of serum (mean \pm SEM, $\mathrm{n}=5$ )

\begin{tabular}{lll}
\hline Serum biochemical parameters & Control & Plant extract \\
\hline Sodium $(\mathrm{mmol} / \mathrm{L})$ & $129.80 \pm 0.70$ & $141.40 \pm 2.30$ \\
Potassium $(\mathrm{mmol} / \mathrm{L})$ & $12.60 \pm 0.00$ & $9.50 \pm 0.00$ \\
Chloride $(\mathrm{mmol} / \mathrm{L})$ & $123.40 \pm 8.44$ & $112.60 \pm 1.95$ \\
Urea $(\mathrm{mmol} / \mathrm{L})$ & $7.44 \pm 1.95$ & $8.56 \pm 0.79$ \\
Creatinine $(\mu \mathrm{mol} / \mathrm{L})$ & $33.20 \pm 5.36$ & $38.60 \pm 4.50$ \\
Uric acid $(\mathrm{mmol} / \mathrm{L})$ & $0.33 \pm 0.09$ & $0.31 \pm 0.06$ \\
Total protein $\mathrm{g} / \mathrm{L}$ & $72.20 \pm 3.56$ & $70.40 \pm 6.23$ \\
Albumin & $29.00 \pm 1.41$ & $27.00 \pm 1.41$ \\
Globulin & $52.20 \pm 3.27$ & $49.40 \pm 5.68$ \\
Albumin/Globulin ratio & $0.66 \pm 0.05$ & $0.62 \pm 0.08$ \\
Alkaline Phosphatase (U/L) & $286.40 \pm 73.02$ & $223.80 \pm 50.80$ \\
Total bilirubin ( $\mu$ mol/L) & $<1.00 \pm 0.00$ & $<1.00 \pm 0.00$ \\
(GGT) Gamma Glutamyl Transferase (U/L) & $<2.00 \pm 0.00$ & $<2.00 \pm 0.00$ \\
(AST) Aspartate aminotransferase (U/L) & $1239.80 \pm 126.60$ & $1162.00 \pm 314.40$ \\
(ALT) Alanine aminotranferase (U/L) & $320.20 \pm 128.52$ & $289.40 \pm 118.70$ \\
Total cholesterol (mmol/L) & $5.70 \pm 0.90$ & $3.20 \pm 1.60$ \\
LDL (mmol/L) & $1.75 \pm 0.30$ & $1.68 \pm 0.40$ \\
HDL (mmol/L) & $1.25 \pm 0.10$ & $1.03 \pm 0.90$ \\
Triglyceride (mmol/L) & $3.64 \pm 1.20$ & $2.58 \pm 1.10$ \\
\hline
\end{tabular}

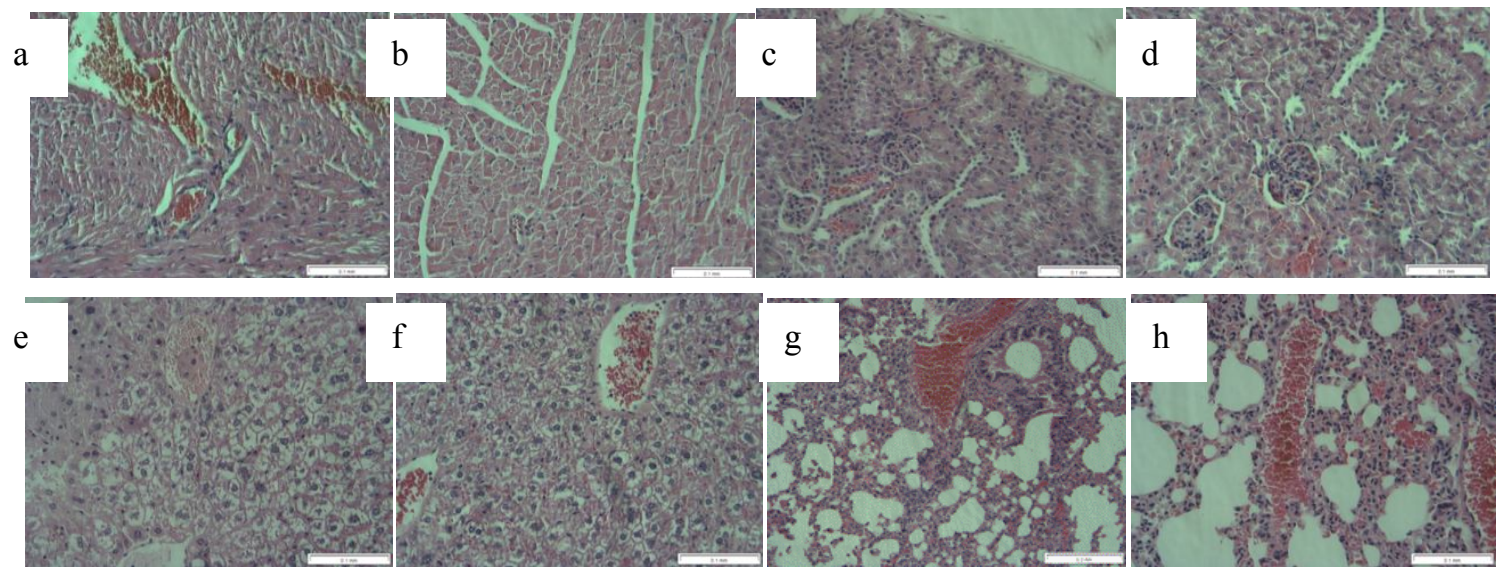

Figure 3: (a) and (b) sections of heart from control group and treatment group (M:Myocardium), respectively; (c) and (d) sections of kidney from control and treatment group (b) ( $G$ = glomerulus), respectively; (e) and (f) sections of liver from control and treatment group $(\mathrm{H}=$ hepatocytes, $\mathrm{S}=$ sinusoids), respectively; $(\mathrm{g})$ and $(\mathrm{h})$ sections of lung form control group and treatment group (b) (AS: alveolar sac), respectively; magnification $=x$ $100(\mathrm{H} \& \mathrm{E})$

mechanism of action of the plant extracts it is useful to assess the toxicity and indicates the cytotoxic nature of the plants and warrants further investigation. Hence further confirmation of the toxicity profile was carried out using acute toxicity study in rats.

Acute toxicity is usually defined as the adverse change(s) occurring immediately or a short time following a single or short period of exposure to a substance or substances [15]. The objectives of acute toxicity tests are to identify the dose causing major adverse effects and also to estimate a minimum dose for the substance or material.

lethality. These can be achieved by using rodents in small groups (3 to 5 animals per group per dose). Acute toxicity studies in animals are conducted using the route intended for human administration, for the administration of the compounds. Rat models are superior to mouse models for testing the pharmacodynamics and toxicity of potential therapeutic compounds, partially because the number and type of many of their detoxifying enzymes are very similar to those in humans [16].

Leaves, flowers and the stem of Mentha spp are frequently used in herbal teas or as additives in commercial spice mixtures for many foods to offer aroma and flavor. The herb is considered a stimulant, carminative, antispasmodic, stomachic and diuretic and is used in the treatment of gas 
pain, rheumatism, toothache, muscle pain [17]. In the acute toxicity assay, the plant extract was well tolerated by the oral route. A dose of 5000 $\mathrm{mg} / \mathrm{kg}$ extract in female rats did not show toxicity symptoms and changes in behavior or mortality. Thus, in the present study, the plant extract could be characterized as non-toxic, as its $L_{50}$ was < $5000 \mathrm{mg} / \mathrm{kg}$ [18]. Although $\mathrm{LD}_{50}$ does not predict a lethal dose in humans it provides a guide to choose a dose for sub-chronic study. Daily administration of the lower dose in the toxicity study provides some indication of the long-term toxicity of the plant extract.

The acute toxicity of the plant extract was determined by assessing the changes in the body weight, food intake, morbidity rate, as well as the hematological, biochemical and histopathological parameters of the animal. Body weight changes and mortality are indicators of adverse effects of drugs and chemicals [19]. The fact that the body weight loss did not significantly differ from that of the control group suggests that the plant extract might not have altered food intake through any mechanisms of appetite suppression.

Organ weight changes are markers of toxicology and risk assessment of drugs, chemicals and food additives [20]. The primary organs which are affected by toxicants are heart, liver, lung, kidney and spleen due to metabolic changes. The weight of major organs of the plant-treated animals did not significantly differ from those of the control group. This implies that the plant extract is non-toxic to these organs, even after administering a dose of $5000 \mathrm{mg} / \mathrm{kg}$.

Histopathological analysis basically provides information on morphological changes in tissue sections by light microscopy. Histopathological examination revealed no toxicity signs in animals treated with the plant extract. The myocardium and heart muscle fibers were normal. Liver, as the central metabolic organ is more vulnerable to toxicants since it is involved in the metabolism of drugs and xenobiotics. However, liver sections of the extract-treated animals did not show any signs of hepatotoxicity and was normal with well defined hepatocytes and central vein. Kidneys, being a prime organ that is susceptible to toxic chemicals since any defect in the tubular function will lead to electrolyte disturbances and nephrotoxicity, also was normal in morphology.

Previous studies have reported mild histopathological changes in uterine and liver tissues of rats exposed to Mentha spicata at higher doses $(20 \mathrm{~g} / \mathrm{L})$ for a longer duration [21]. In the present study, there were no histological changes in the tissues of the rats exposed to (5000 mg/kg) of Mentha spicata, except for a slight numerical changes of the liver enzymes which was not statistically significant.

No toxicologically significant hematological differences between animals treated with the plant extract and control animals were observed in this study. Changes in clinical biochemistry parameters in the animals treated with the plant extract were insignificant except for reduced cholesterol levels. The increased total protein levels and reduced total bilirubin levels observed were also not of statistical significance.

\section{CONCLUSION}

The results obtained show that Mentha spicata extract is non-toxic in sub-acute and acute dose of $5000 \mathrm{mg} / \mathrm{kg}$. Since the plant is consumed as a culinary herb, it means it can be safely taken in amounts that do not exceed the equivalent of the extract dose of $5000 \mathrm{mg} / \mathrm{kg}$. Same applies for its herbal medicinal use. Our findings may lend some support for the claimed medicinal use of the plant for several decades without apparent untoward effect.

\section{REFERENCES}

1. Balick MJ, Cox, PA, Plants, People, and Culture: the Science of Ethnobotany. Scientific American Library, New York, NY; 1997.

2. Gurib-Fakim A. Medicinal plants: Traditions of yesterday and drugs of tomorrow. Mol. Aspects. Med 2006; 27: 1-93.

3. Lawrence BM. Mint: The Genus Mentha, CRC Press: Boca Raton, FL, USA, 2006.

4. Znini M, Bouklah M, Majidi L, Kharchouf S, Anouniti A, Bouyanzer A, Hammouti B, Costa J, Al-Deyab, SS. Chemical composition and inhibitory effect of Mentha spicata essential oil on the corrosion of steel in molar hydrochloric acid. Int. J. Electrochem. Sci. 2010; 6: 691-704.

5. Daferera DJ, Ziogas BN, Polissiou MG. The effectiveness of plant essential oils on the growth of Botrytis cinerea, Fusarium sp and Clavibacter michiganensis. Crop. Prot. 2003; 22: 39-44.

6. Kaur C, Kapoor HC. Antioxidants activity and total phenolic content of some Asian vegetables. Int. J. Food Sci. Technol. 2002; 37: 153-161.

7. Akhilesh Kumar, Sharmila Chaatopadhyay. DNA damage protecting activity and antioxidant potential of pudina extracts. Food Chem. 2007; 100: 13771384.

8. Krishnaraj, AV, Rao TVN, Sundararaju D, Vanisree $M$, Tsay HS, Subbaraju GV. Assessment of Bioactivity of Indian Medicinal Plants Using Brine Shrimp (Artemia salina) Lethality Assay. Int. J. Appl. Sci. Eng. 2005; 3: 125-134.

9. Kavitha Bhagya S, Rajashree PV, Sam KG, Preliminary anticancer screening and standardization of some indegenous medicinal plants using cell-biology and molecular biotechnology based models. Res. J. Med. Plant 2011; 5: 728-737.

10. Babu A V, Rao RSC, Kumar KG, Babu BH, Satyanarayana PVV. Biological Activity of 
Merremia emarginata Crude Extracts in Different Solvents. Res. J. Med. Plant 2009; 3: 134-140.

11. OECD Guideline for Testing of Chemicals. No. 425 Acute Oral Toxicity -Acute Oral Toxicity -Up-andDown-Procedure (UDP), Organisation for Economic Co-operation and Development: Paris, France, 2008.

12. Jegathambigai $R$, Othman I, Normadiah MK, Kumar $P$ Effect of Isoflavones, Genistein and Diadzein on the Ovaries of Neonatal Mice. J. Ecobiol. 2011; 28: 1-7.

13. Carballo JL, Hernández-Inda, ZL, Pérez P, GarcíaGrávalos MDA comparison between two brine shrimp assays to detect in vitro cytotoxicity in marine natural products. BMC Biotechnol. 2002, 2: 17.

14. Logarto PA, Silva YR, Guerra SI, Iglesias BL. Comparative study of the assay of Artemia salina L.and the estimate of the medium lethal dose (LD50 value) in mice, to determine oral acute toxicity of plant extracts.Phytomedicine. 2001; 8: 395-400.

15. Rhodes $C$, Thomas $M$, Athis J. Principles of testing for acute toxic effects. In General and Applied Toxicology, Ballantyne B, Marrs T, Turner P, Eds.;
Stockton Press: New York, USA, 1993; Volume 1: $p$ p 49-87.

16. Lindblad-TohLindblad-Toh, K. Genome sequencing: three's company. Nature 2004; 428: 475-476.

17. Moreno L, Bella R, Primo-Yufera E, Esplugues J. Phramacological properties of the methanol extract from Mentha suaveolens Ehrh. Phytother. Res. 2002; 16: 10-13

18. Zbinden, G.; Flury-Roversi, M. Significance of the LD50 test for the toxicological evaluation of chemical substances. Arch. Toxicol. 1981; 4: 77-99.

19. Hilaly, J.E.; Israili, Z.H.; Lyouss, B. Acute and chronic toxicological studies of Ajuva iva in experimental animals. J. Ethnopharmacol. 2004, 91: 43-50.

20. Michael B, Yano B, Sellers RS, Perry R, Morton, D Roome N, Johnson, JK Schafer, K Pitsch, S. Evaluation of organ weights of rodents and nonrodent toxicity studies: a review of regulatory guidelines and a survey of current practices. Toxicol. Pathol. 2007; 35: 742-750.

21. Akdogan $M$, Ozguner $M$, Aydin $G$, Gokalp $O$. Investigation of biochemical and histopathological effects of Mentha piperita Labiatae and Mentha spicata Labiatae on liver tissue in rats. Hum. Exp. Toxicol. 2004; 23: 21-28. 